Article

\title{
The Effect of Employee and Customer Religious Beliefs on Business Operating Decisions
}

\author{
Richard Metters \\ Mays Business School, Texas A\&M University, MS 4217, College Station, TX 77843-4217, USA; \\ rmetters@mays.tamu.edu
}

Received: 31 May 2019; Accepted: 12 August 2019; Published: 15 August 2019

\begin{abstract}
Business operating decisions and procedures can differ depending on the religious beliefs of either employees or customers. We provide examples of religion affecting operations in the topical areas of location, layout, shift scheduling, and operational compliance, among others. These issues are especially salient for global corporations extending operations overseas utilizing expatriate management.
\end{abstract}

Keywords: operations; supply chain; location

\section{Introduction}

Consider the following scenario affecting operational compliance in a business situation. The decision maker is an expatriate U.S.-based operations manager working in a Malaysian factory only 80 miles from the capital, Kuala Lumpur. Without any prior warning, a worker "started sobbing, laughed and then shrieked. She flailed at the machine ... she was violent, she fought as the foreman and technician pulled her away" (Ong 1987, p. 207). In a few minutes, the same thing then happens with other workers. Within a half-hour, like in a science fiction movie, 100 or more workers are screaming and beating on their machines. The rest of the 1500 workers, while unaffected, have stopped working and are frightened. Production is at a standstill. What is happening? What do you do?

What is happening? Religion-spiritual belief.

"It is a common belief among workers that the factory is 'dirty' and supposed to be haunted by [an evil spirit]". According to a worker, "a piercing scream from one corner of the shop floor was quickly followed by cries from other benches as [workers] struggled against spirits trying to possess them. They would struggle so hard that sometimes ten supervisors could not control one afflicted worker." "The factory shut down for three days and a spirit-healer was hired to slaughter a goat on the premises. The American director wondered how he was to explain to corporate headquarters that '8000 h of production were lost because someone saw a ghost'" (Ong 1987, p. 204).

This was not an isolated incident. Many other examples will be provided. While nominally Muslim, many of the workers also believed that various spirits inhabit the world. Seemingly contagious "spirit possession" could take hold, shutting down operations. These spirits do not only attack at work. They are part of their everyday lives. What Westerners call post-partum depression is obviously the work of spirits that inhabit the body to these people (Ong 1988, p. 31). Likewise, depression due to widowhood or divorce is blamed on spirit possession in this society (Kessler 1977). Spirit possession is simply part of their everyday activity and is accepted as a reason for a wide variety of ailments. Why would it not also affect the workplace?

Interviews with these workers indicate that they believe possession by spirits truly has occurred, and may very well reoccur. Complicating matters, afterwards workers directly afflicted report no knowledge of the event occurring. 
The follow-up question is, what to do? One management response could be to tell the workers "get back to work- there are no spirits here" and to fire those workers hopelessly disruptive due to their "possession." Unfortunately, that is not a realistic option. Even workers that were not "possessed" would not return to such a work environment for fear of the spirits, and the firing of a worker for being involuntarily possessed seems grossly unfair to them. An approach that is more religiously aware-and seems to work better-is to "call the bomoh [local shaman] to come, every six months or so, to pray, walk around. Then we take pictures of the bomoh in the factory and hang up the pictures. Somehow, the workers seeing these pictures feel safe, that the place has been exorcised" (Ong 1987, p. 205).

The above operational compliance experience may seem bizarre, but it is far from unique. This article is concerned with how the religious beliefs of employees and customers change business operating decisions - which will be demonstrated by many such examples. While the above scenario seems to be a temporary operational challenge, it is not. It is a repeated game that is played over many firms in many countries. Other operational adaptations to religious beliefs are more permanent in nature, changing such core operational decisions as location, layout, shift scheduling, and many more.

From the perspective of management, this was a shocking and unpredictable business problem. Management was from countries halfway around the world and they were unaware of the religious beliefs of their workers. However, from the perspective of anyone who was familiar with the workers' religious beliefs, this is an easily foreseen event. "Locals" would have planned for it. We extend this dichotomy to the goals of research in general. Ignoring religion, researchers may produce "generalizable" research that does not actually generalize. We argue here that an additional theory of generalizability is called for: "generalizability of context", rather than our usual "generalizability of topic", an argument to be expanded upon in the next section.

This work is a collection of data points like the one above. As a generality, the collective thrust supports the theoretic principles of "postmodernism" and "postsecularism" (e.g., Woodhead et al. 2016, pp. 27, 490) as opposed to "positivism." That is, in the case of religion in the workplace, there are many exceptions to the positivist theory that there is truth that transcends time and place. However, we do not advance a particular theory. We proceed as noted by (Woodhead and Partridge 2016, p. 37) in their treatise on religion in the workplace: "(o)ther scholars prefer an inductive approach, which, instead of relying initially on a theory, begins with an examination of a wide range of data on a subject. Once data has been collected and analyzed, it is then used in the development of theory for later use." We believe this pre-theory approach to religion and Operations Management is apropos due to the paucity of work in the area. The Operations Management literature has, literally, no articles that focus on or even mention religion. Introducing Ewest's book on the topic of faith and business, (Ewest 2018, p. 1) notes "the importance of faith and work within organizational life, which identified as foundational, is still formative and at times lackadaisical ... Consider (Mitroff 2003) whose research was considered seminal in the emergence of the field of spirituality in the workplace, who states, "I still believe that formal, organized religion has very little, if any, role to play in the workplace" (Mitroff 2003, p. 378)." That is, there is a lack of data, and a predisposition of scholars not to be aware of examples. As a further example of the lack of data concerning Operations Management in the religion and business literature, the 1000 page edited volume of (Stackhouse et al. 1995) contains 13 articles on the "ethics in specializations of business" including sections on Marketing, Finance, Accounting, and Human Resources. There is not a single article on "Operations Management". Miller and Ewest (2013, p. 29) state that previous research does not show how religion "manifests itself in the workplace." This work is intended to fill that gap.

The focus here is on the potential clash of religions involving expatriate Western management and their international assignments. McCann $(1995$, p. 3) states that knowledge of different religious views "(I)s especially true for students preparing for careers with an international focus. If you plan to work for a multinational corporation, for example, you are likely to encounter a multiculturalism that 
raises theological issues ... The religious terrain ... is no longer the Protestant franchise ... How can American firms compete ... without understanding their own ... religious assumptions?" (emphasis added).

Before beginning, a preface is appropriate: the evidence provided here comes from sources not typically seen in this journal. Most of the information comes from the fields of medicine, developmental economics, anthropology, and women's studies. Frequently the anthropological and women's studies works are ethnographic studies of one or a few workplaces in a particular country. The "ethnographic" method for these works usually means that one or a few firms are studied intensively, for weeks, months, or even years, as opposed to broad cross-sectional surveys of businesses. As shorthand, we write "given employees who believe in religion $X$, Jones found that ' $Y$ ' occurred." Strictly speaking, this means that ' $Y$ ' was found in these specific companies, in specific places. It is not a statement that ' $Y$ ' is found in all companies with employees of religion $X$ throughout all time.

To set the stage, reflect on the historical impact of religion on business operations. For millennium, religion has been a central organizing principle for economic activity in general, and a cause for operations management and supply chain practices in particular. This has been true in widely disparate regions of the world. A few examples from geographically distant places:

- $\quad$ Africa: The construction of the over 100 Egyptian pyramids thus far found required a large, though unknown, percentage of GDP, required operational techniques normal life did not, and caused the need for labor specialization and supply chain operations (moving from quarry to placement and stacking of multi-ton stones). It impacted location decisions as well, as a fairly recent find of the "workers village" indicates a city dedicated to housing up to 20,000 full-time pyramid construction workers over the course of several projects (National Geographic 2016).

- Europe: in the 1300's cathedral construction required massive amounts of stone to be quarried, moved, and cut. The populace largely lived in mud or wood walled homes. The process of building 100 foot tall edifices was the only construction at the time that required scaffolding.

- $\quad$ South America: The entire city of Machu Picchu (Peru, circa 1300) is thought to be largely built for ceremonial and religious purposes. Relatedly, in the Inca Peruvian town of Sacsayhuaman, built between 1100 and 1300, hundreds of thousands of tons of stone were hauled 12 kilometers, uphill, with no pack animals, to commemorate their gods. The largest single stone weighed 120 tons, which no doubt consumed enormous resources.

- $\quad$ Asia: The Potala Palace in Tibet was built in 1645 to be the home of the Dalai Lama, their religious leader, and was the largest building in Tibet with over 1000 rooms. At the time of the Chinese takeover in 1959 it is estimated there were 6000 Buddhist monasteries in Tibet supporting a population of 1.2 million, and 1 in 6 men were monks/lamas (BBC 2018; Tu 1997). The stupa (mausoleum) of the 5th Dalai Lama contains 3727 kilograms of gold (today worth $\$ 150$ million) 18,680 pearls and other semi-precious stones.

This influence is not relegated to the past. An obvious current day effect on operations is the induced seasonality in the sales of many products due to Christmas. While many non-Christians give gifts, if Christianity were not here, the massive seasonal production planning problem that the Christmas season artificially creates would not be with us. Other easily discernable operational issues stem from shift scheduling and businesses being voluntarily or by law closed for the Sabbath day (e.g., liquor stores in many U.S. states).

The examples above are meant to prime the reader with the importance of religion to business, but are not the focus of this work. The seasonality of toy sales will not be a surprise to, say, a non-Christian Chinese manufacturer. Instead, the focus here is on what surprises management, requires new thinking, or what causes Operations Management research results to be incomplete.

In the next section the scant literature is reviewed and the theoretical lenses for viewing this material are discussed. The remainder of the manuscript provides examples of religion changing operations. Only one side of the religion/operations equation is given proper treatment in this manuscript: the perspective of religion as a constraint. It should be noted that religion is a galvanizing 
force in many companies, and the shared values and mission that a common religious baseline creates among employees is a key aspect of the success of many firms.

After the next section, this work is organized by religion, as depicted in Table 1. A large number of examples are drawn from indigenous, non-organized religious traditions usually described collectively as "Animism". That is, the belief that spirits reside in places or objects. Adherents to a variety of Animistic beliefs are found worldwide, and examples are provided as to how these beliefs have the power to shut down corporate operations. Examples are also provided on the effect the major organized religions of Islam, Judaism, Confuscianism, and Christianity have on business operations.

Table 1. Effect on business operations by religion.

\begin{tabular}{lll}
\hline Religious Tradition & Countries Used in Examples & Issue/Operational Concern \\
\hline Animism & $\begin{array}{l}\text { S. America: Bolivia, Peru; } \\
\text { Asia: Cambodia, Malaysia, Nepal, Singapore }\end{array}$ & Operational shutdown \\
\hline Islam & Bangladesh, India, Pakistan & $\begin{array}{l}\text { Factory location; Shift scheduling; } \\
\text { Office layout }\end{array}$ \\
\hline Judaism & Israel & Technology use; Gender segregation \\
\hline Confuscianism & S. Korea, China & Contract adherence \\
\hline Christianity & USA & Medical operations \\
\hline
\end{tabular}

\section{Literature Review and Theory}

\subsection{Prior Literature}

There is substantial literature on spirituality and business, but we find no literature concerning religion and Operations Management. This lack does not occur in other business disciplines. There are several journals dedicated solely to Islam in Finance (e.g., Journal of Islamic Finance, International Journal of Islamic and Middle Eastern Finance and Management, among others), Accounting (e.g., Journal of Islamic Accounting and Business Research), and Marketing (e.g., Journal of Islamic Marketing, International Journal of Islamic Marketing and Branding). The field of Management has the Journal of Management, Spirituality E Religion.

A few articles have appeared in journals edited by largely North American editorial boards. The journal Management Science is often cited as the leading journal for business operating decisions. But searching on the terms "religion," "religious," "Islam," "Protestant," "Christianity" and other related terms in this journal found only two articles, neither related to operating decisions. A Finance article comparing investment strategies of Protestants and Catholics (Shu et al. 2012) and an article on the organizational structure of German Catholic and Protestant hospitals (Filistrucchi and Prüfer 2018). (Note: "Christian" and "Catholic" are not useful search terms due to the large number of authors named Christian and the large number of universities with the word Catholic in their name). There is one article involving religion in a top accounting journal (McGuire et al. 2011) and one in a top marketing journal (McAlexander et al. 2014). Searches on the relevant terms in other primarily business operating decision journals (i.e., the field of "Operations Management") produced no results.

However, there is indirect research that forms a bedrock for this effort.

There is research that documents that Operations Management practices are different in different parts of the world (e.g., Abdul-Aziz et al. 2000; Adam et al. 1997; Chin et al. 2002; Corbett et al. 1998; Raghunathan et al. 1997; Rao et al. 1997; Rungtusanatham et al. 2005; Tata et al. 2000; Yavas 1995; Zhao et al. 1995). The purpose of this literature is to document differences, and potential reasons for those differences are largely not explored. Most of these papers document different quality management practices. The Global Manufacturing Research Group database has been utilized in over 60 publications (GMRG 2018). The vast bulk of these works document different Operations Management practices across either countries or regions of several countries. Due to the sheer volume of work on this subject, we consider it a fact that many Operations Management practices differ. Perhaps a "one best way" 
exists, perhaps not, but if it does exist, it is not followed well. Our argument here is that religion is a proscribing factor in determining the feasible set for a local "one best way".

\subsection{Theory}

For the purposes of our current effort, the "international differences" literature above is unsatisfying due to the lack of causation. Without an understanding of why practices differ, it is difficult to make predictions and the work lacks generalizability. National Culture and Operations Management work does provide such reasons. Largely, cultural explanations are sought to determine whether an Operations Management process or topic is subject to "national specificity." A recent review found 83 articles that are mainly concerned with national culture and Operations Management (Metters et al. 2019). All but a few of those articles found that national culture makes a difference in which Operations Management practices are used or a difference in the results gained from the same practices. National culture and religion are related, but ultimately different. Where one religion is monolithic in a country it may be difficult to parse them. However, consider India, the world's largest Hindu nation-and the world's second largest Muslim nation. Nigeria is split nearly evenly between Christians and Muslims. The list goes on. National culture research attempts to state that, for example, "the culture of India favors Operations Management practice X". We believe this is incorrect in essence. Instead, we should search for the statement "the Islamic portion of India favors practice X."

This work seeks to challenge and broaden the traditional notion of "generalizability" in the dominant approach to research. In quantitative, theorem-proof research, a problem is typically reduced to mathematical expressions. Once the problem is translated mathematically, we agree that any solution to that mathematical expression will be a general one. The vast bulk of this research remains unchallenged by us. However, for certain business situations that will be discussed, we "deny the premise" of the mathematical formulation. That is, ignoring religion can lead to inappropriate objective functions and missing constraints. For survey research "generalization" means that the results can be applied beyond the sample. There are a large number of statistical metrics to determine the probability of the sample representing the mean result of a population. Our contention is that-sometimes-the notion of there being a single "population" is inappropriate. There do exist population means, but there are several distinct populations (religions) each with their own mean values and that mixing them is akin to stating the average color of paint is grey when one has 10 buckets each of black and white paint.

However, the argument we bring to bear is more fundamental. We argue that, in some cases, what is appropriate and leads to more predictive power is "generalizability of context." The argument is that context can be essential to external validity. The arguments concerning the existence and interplay of these issues was the topic of the so-called Calder/Lynch debate in Marketing (Calder et al. 1981, 1982, 1983; Lynch 1982, 1983). Generalizability of context is an unstated lynchpin of cultural Anthropology as an entire field. At its core, generalizability refers to applying findings made in one case to others. The central idea is that religious knowledge confers predictive power as to what additional constraints or opportunities are available across topical areas.

A framework that is well suited for displaying this broader notion of generalizability lay in a measured construct by Trompenaars (1994) called the "universalism-particularism" spectrum. Universalism can be viewed as the standard version of generalizability: that which is true in one place is true in all places over all time. For the purposes of this manuscript Universalism means that a process performing well in one place can be written down, the equipment packed up, then reassembled in a different place where the new employees are instructed in process parameters, and the process remains the same. This is the general argument for process offshoring - get the same quality, response time, and flexibility, but take advantage of international labor arbitrage to cut costs. A Particularist views this reasoning as suspect. This viewpoint states that culture, laws, or geography may militate against operational replication. Here, we add another important aspect to the Particularist reasoning: Religion. 
From this point forward the focus of this manuscript is on specific cases that demonstrate the effect religion has on Operations. The overall reasoning is inductive-we reason that, from the many specific cases, there is a general point of religion intertwining with Operations Management.

\section{Animism}

We return to the example that introduced this manuscript. There is not a specific, named religion associated with the belief in spirits associated with indigenous Malays. Likewise, around the globe many indigenous peoples will self-identify with a major organized religion, yet still harbor local, long-held, animistic beliefs.

In the case of the Malaysian factory, Animism in general, and the belief that these spirits can possess people in particular, cause a factory shut down. As noted previously, this case is not isolated. Ong (1988) chronicles many other cases in Malaysia. Phoon (1982), a researcher employed by the Singapore health directorate, documented half a dozen such outbreaks in Singapore involving disparate corporate environments such as processing food, electronics assembly, manufacturing batteries, and a service environment of a telephone exchange. The pattern is the same as the one depicted: one employee starts screaming and faints, then subsequently others do the same. In others, employees had hysterical seizures or entered trance states where they believe demons spoke through them.

More recent examples are the mass faintings in Cambodian factories over the past several years (Marshall 2011; Wallace 2014). Hundreds of workers faint while on the job, because the factory is inhabited by the local guardian spirit "neak ta". Some of the workers claim the spirit speaks through them, with one demanding an offering of raw chicken. "Peace, and production, resumed only after factory owners staged an elaborate ceremony, offering up copious amounts of food, cigarettes and Coca-Cola to the spirit" (Wallace 2014). Spirits in the workplace led to walk-outs in Nepal that were only quelled when "factory management agreed to hire a medium" (Anonymous 2014). Walkouts and vandalism in Bangladesh (Radford 2013) and Pakistan (Anonymous 2013) were caused by workplace demons. In the Western medical community, these operational compliance problems are called "mass psychogenic illness" rather than "spirit possession." There were a sufficient number of these incidents to justify the article "a review of mass psychogenic illness in work settings" (Colligan et al. 1982). In general "spirit possession" has been reported in 437 of 488 societies across the world (Crapanzano 1977, p. 7), so it is not unexpected that it would occur in the workplace.

Let us look for the non-spiritual causes for this phenomenon. The Cambodian mass faintings are attributed to poor operational conditions combined with an inability to demand operational change from management. Similarly, for the Malaysian workers, the anthropologist Ong title her work "Spirits of Resistance." In her view, the workers were protesting operational conditions in the only manner available to them - though the workers themselves would deny that statement and insist they were actually inhabited by evil spirits. Phoon describes the situations in Singapore as characterized by excessive work pressure, excessive required overtime, and not listening to the complaints of workers. Over the literature cited here, and a considerable literature not cited, it is generally agreed that enlightened management practices normally associated with Total Quality Management and Lean act as a preventive for spirit possession in the workplace.

This work shutdown can take other forms. An oil exploration group in the Peruvian jungle made this report: "We hired local inhabitants to support our geological expeditions. They believed in the existence of El Tunchi. El Tunchi is a spirit that goes after those who damage the jungle. Natives can read signs from nature that indicate the presence of El Tunchi. For example, they believe that when El Tunchi lies in the Jungle to have a rest, the vegetation does not grow around as vigorously. They also believe that when a group of mushrooms grows forming a circle it represents El Tunchi's bed. When working in Peru, the crew found one of these groups of mushrooms, they were so scared that they just dropped all the equipment and ran away in all directions. Some of them refused to return to pick the equipment and it took a while to reorganize the entire group. Some equipment was lost." (Cabanas 2014). 
Religious beliefs that effect operations abound in the mining industry. Nash (1993) and Taussig (1980), both Anthropologists reporting on tin mines in Bolivia, state that the miners will respond to queries that they are Christian, but that Christ only has dominion above ground. In the mines, the spirit of Huarte (also called Tio) has control. Huarte is the reason for mine deaths, not faulty structural engineering or improper ventilation. If accidents occur, workers will not return to the mines unless Huarte is appeased, usually by sacrificing a llama. Fixing the mine structure is not sufficient to get the workers to return to work. Conversely, fixing mine structure is not necessary to get miners back to work-the sacrifice to Huarte is enough.

In current day Peru most underground mines are worked largely by the Kechuan minority group who, while nominally Christian, retain Incan beliefs (Ganoza 2018). According to these beliefs, the mountains themselves are spirits. Beyond the mountain spirit, a particular mine devil usually called "muqui" is thought to cause problems. Some years ago, workers would not enter a new mine unless a sacrifice of a llama heart wrapped in coca leaves is placed at the mine entrance. Even today, the miners will not enter a mine that has had issues unless appropriate sacrifices are made (usually alcohol). This should be seen in context. This ethnic group sacrifices a llama or sheep heart in their non-working lives for many events. For example, if they want luck in seeking a job or farmers wishing for a good harvest, such sacrifices are made. This is common in this part of the world-llama fetuses are available in open markets in La Paz, Bolivia, to purchase for everyday sacrificing to these gods (Shahriari 2017).

A related superstition in Peru concerned women working in the mines. Miners believed muqui was offended by women workers and male workers would refuse to enter a mine if a woman was present. Mining executives in Colombia and Zambia also reported the belief that Satan ran the mines and would be incensed by women entering (Continental Gold 2018; Zambia Chamber of Mines 2015). When mining executives were asked whether they would ignore the workers superstitions and tell them to get back to work, the response was: "We're not that stupid. The miners feel more safe when their traditions are honored."

The "hidden people" or huldufólk are part of folklore in Iceland and in the Faroe Islands. Some call them "elves." Regardless, none has ever been found-of course-and belief in them is similar to believing in "spirits." How many Icelanders believe in elves? "If you rephrase it to include those not willing to deny the existence of elves, you would come close to 100 percent" (Goreau 1996).

This belief system has operational connotations. Construction workers often refuse to build projects if they believe they are disturbing the homes of these creatures. "For the huge Kárahnjúkastífla dam project in the east, consultants with clairvoyant skills were hired to check out the landscape first to ensure it was empty of elvish rocks" (Wainwright 2015). Highways detour around suspected elf homes (Goreau 1996; Lyall 2005). "The Icelandic road and coastal administration abandoned plans to blow up a hill in Trollaskard after not being able to reach an agreement with the hidden people" (Hauksdottir 2016). The official position on the existence of elves is "It will not answer the question of whether the (Icelandic Road and Coastal Administration) employees do or do not believe in elves and 'hidden people' because opinion differs greatly on this and it tends to be a rather personal matter" (Hines 2018).

Regardless, if a multi-national firm wishes to construct a building in Iceland, such as Alcoa (Lewis 2011), the elves must be consulted. If they can be found.

\section{Judaism}

In certain Ultra-Orthodox Jewish communities, many Islamic communities, and among some Hindus, men and women must be separated. In this section we focus on the ramifications in Judaism, and focus on Islam in the next section.

Sex segregation has many operational implications. 


\subsection{Transportation/Revenue Management}

Airlines frequently have problematic passengers that refuse to sit next to a person of the opposite sex due to religious reasons. Some who oppose sitting in mixed gender transportation purchase two tickets to ensure this does not occur, others do not. A small number of such passengers can be accommodated by flight crews. There are a number of accounts of Ultra-Orthodox Jewish men who flatly refuse to take their seats if they are seated next to women. Occasionally there are simply too many of them to accommodate and flight delays ensue (e.g., El Al Airline Staff 2018; EasyJet Harpin 2017; Austrian Airlines Mehta 2018). Further, accommodation may now be illegal in certain airlines, as it is now against the law in Israel to ask a woman to move seats so she won't be sitting next to a man. This is a particular problem for United Airlines-but only on the New York-Tel Aviv flight. The solution: deleting a row of seats from the revenue management system and not allowing their sale so that these men can be seated in this empty row to avoid sitting next to women (United 2017).

In general, public transportation is presented difficulties due to mixed gendered seating. For some time in the 1990's Jerusalem and Bnei Brak operated two parallel bus lines-a bus line that only took women and children and a bus line that only transported men (Shapira-Rosenberg 2010). Of course, operationally this means different, smaller buses are needed, more drivers are required, etc. Even basic bus usage cannot be forecast from typical population patterns. In Israel "the ultraorthodox communities are highly dependent on public transportation services" (Guggenheim and Taubman-Ben-Ari 2014) because the men are frequently dedicated to religious study, and the women are the breadwinners and must go to work, but are prohibited from driving due to religious edicts.

\subsection{Segregated Public Accommodations}

Tourists in Jerusalem quickly note that at the Western Wall (aka, the Wailing Wall) there are separate areas for men and women. If a woman attempts to enter the men's area she is physically detained. This segregation has, at various times, extended to all public accommodations-swimming pools, supermarkets, banks, the post office, etc. Either separate times for men and women are enforced or they join separate lines-with the attendant queuing issues (a full listing of gender segregated Israeli public accommodations is in Shapira-Rosenberg 2010). The segregation of public pools, clearly against U.S. law, also takes place in Brooklyn, New York, in a Jewish neighborhood (Anonymous 2016). (The prohibition against those of different genders swimming together also exists in the Christian sect "Church of God"). Operationally, this requires scheduling of appropriately gendered employees at certain times.

Although Israel is known as a Jewish state, note that we only mention Jerusalem. None of these practices take place in Tel Aviv. So, one cannot label this a cultural artifact of Israel—it is strictly a religious aspect that pertains to a portion of Israel.

\subsection{Technology}

Technology in general and the advent of the internet and the possibility for searching for "unapproved" images or ideas in particular has been a concern for several disparate religious belief systems. Here, we focus on examples from Judaism.

The Judeo-Christian tradition has adopted a variety of rules dealing with the mandated "day of rest" each week. Some firms simply close for business on their favored day of the week. In Israel, the public transportation system shuts down Friday at sunset for Shabbat. These customs only take tourists by surprise.

However, there are further restrictions among some groups that are less known and require local knowledge and planning for businesses. Some Jews believe that not only should they rest, but they adhere to the principal that they cannot even cause "work" to be done on Sabbat by others. "Work" is broadly construed and one meaning is that no electricity can be engaged. So, light switches cannot be turned on or off. Elevator buttons cannot be pressed. Accordingly, hotels, hospitals, apartment 
buildings—any business that has a multi-story building and operates on Shabbat-that wish to have these customers as guests need different technology. The so-called "Shabbat elevator" continuously runs and does not need to be called. It stops on every floor (some on every other floor) automatically. Usually, this is only one in a bank of elevators. While this is well-known-and the law-in Israel, adopting this technology requires a knowledge that a potential religious customer base exists in other countries-and Shabbat elevators can be found in many other countries.

As noted previously, observant Jews cannot turn on electric lights on Shabbat. A technology that can be installed is a "Shabbat" button that can be pressed by hotel, hospital, etc., occupants before Shabbat starts that turns on and off lights at appropriate times, or in a low-tech version, alerts hotel employees to enter the room at certain times to take care of lighting issues.

Due to the possibility for inappropriate images or viewpoints to be seen, there are also "kosher cellphones." These phones have far fewer features than regular cellphones, including a lack of SMS capability and the lack of voicemail since "the sound of the female voice poses too great a temptation to men" (Campbell 2010, p. 164). Kosher land-lines also exist. Seeing this market niche, and creating the specialized processes for manufacture, required specific contextual knowledge.

\section{Islam}

Gender segregation is often called "purdah" in Islam. In the more extreme interpretations, women cannot be seen by men not of their immediate family, hence the well-known burqa that offers complete physical coverage of a woman's body. However, "purdah is better understood as the broader set of norms and regulations that promote the seclusion of women, enforce their exclusion from public spaces and give specific gender identities to labor" (Amin 1999, p. 219). It is not the purpose of this article to either condemn or support, but the reason for purdah is seen by its adherents as protecting women. The "pro" argument is that sex segregation protect women from being harassed or seen as sex objects. The "con" argument is that purdah oppresses women.

The operational issues seen in Islamic countries due to this issue are larger than usually witnessed in Judaism.

\subsection{Transportation}

The usual solution to segregated bus travel in Islamic countries is to reserve a space at the front of the bus solely for women. However, the number of seats is limited, and those front rows are often full, causing the women to miss a particularly timed bus on the way to work. Even when they sit in the area specifically designed for women, the buses are physically small, and the male bus drivers' hand can frequently come into contact with them as he shifts gears, which is an unacceptable contact between genders to some (Khattak 2002).

In a similar manner, the Paris, France transit authority reported that "several" male drivers refused to work when they discovered they drove directly after a female driver (Clark 2016). There are several subway systems around the world that have women-only cars. Many of these are for the purpose of reducing sexual harassment and are not religiously based-but some are.

\subsection{Location}

The most significant operational problem due to gender segregation is facility location. Location modeling in the Operations Management literature usually focus on cost minimization. Consider the following fatwa from an Islamic Imam:

"It is permissible for a woman to go out of her house for work, but that is subject to certain conditions. If they are met, it is permissible for her to go out. They are ... The work should be suited to the nature of woman, such as medicine, nursing, teaching, sewing, and so on. The work should be in a place that is only for women, and there should be no mixing with non-mahram men [note: "non-mahram men" are usually close relatives that must escort a woman when she is out of the home]. Her work should not lead to her travelling without a mahram. Her going out to work 
should not involve committing any haraam [prohibited] action, such as being alone with the driver" (Al-Munajjid 2018).

Islam does not have a central authority-there is no equivalent to a Catholic Pope-so this fatwa is not universal. However, it captures the spirit of Islamic practice in many parts of the world.

Due to gender segregation there is a general choice: the workforce must be either entirely male or entirely female. Workers of the same gender cannot be shoulder to shoulder. (It is acceptable to have female workers and male supervisors-providing an appropriate distance can be kept).

The transportation difficulties mentioned above combined with all women workplaces leads to a location decision that is not encountered in Operations Management textbooks: it leads to a strong preference for very local employment—as in within walking distance, since catching the bus to work is highly unreliable. This desire for a job very close to home is reported in Istanbul (Dedeoglu 2008, p. 156) and Bangladesh (Dannecker 2002). This has operational consequences. Rather than one large factory that can take advantage of scale economies, many smaller factories would be favored. This partially accounts for the 5000 garment manufacturing factories said to be in Bangladesh.

\subsection{Homework}

Another Islamic fatwa:

"Allaah says (interpretation of the meaning): "And stay in your houses, and do not display yourselves like that of the times of ignorance" [al-Ahzaab 33:33]. Although this is addressed to the wives of the Prophet (peace and blessings of Allaah be upon him), it also applies to the believing women." (Al-Munajjid 2018)

The most striking ramification concerning purdah is whether to have a location at all. Where purdah is practiced in a strong sense, "female employment is considered a disgrace ... and is seen as a fall in social standing of the concerned family" (Mirza 1999, p. 188). There is a sliding scale of purdah observance with more strict observance seen as a status symbol among its adherents (Dannecker 2002).

Consequently, in many parts of the world factories in many industries would not be built. Instead, the work is brought to the woman's home, rather than the woman going to a factory. The work is diverse, but in keeping with the earlier fatwa, it is usually work reserved for women: sewing zippers or lining onto garments, assembling electronic or plastic devices, shoemaking, packing industrial shipments, even peeling shrimp (Rowbotham 1993). This type of employment is typically termed "industrial homework" to distinguish it from work as a maid, or knitting as a pastime with an occasional craft sale. ("Homework" is not "domestic work". Homework is industrial work performed in one's own home, domestic work is done in someone else's home.) The International Labour Organization (2012) claims there are 100 million such workers world-wide, $80 \%$ of whom are women, with somewhere between $25 \%$ to $60 \%$ of the garment and textile global workforce structured this way. The estimate is wide ranging because this labor is usually off the official books. For example, it appears only $2 \%$ of Turkish shoemakers and $8 \%$ of carpet manufacturers are government registered (Dedeoglu 2008, p. 47).

Outside employment is seen as violating purdah, being paid for doing the same work at home is not. Discreet homework is acceptable. It is viewed as "helping out". In certain parts of Turkey, women working at a factory is frowned on, but doing the same work at home for pay is "just passing time" (Dedeoglu 2008, p. 121). In a survey of Pakistani women workers 33\% preferred home-based work even though the pay is less because they "don't think it's right" to work outside the home, while $52 \%$ state that there would be objections from family members to working outside the home (Khattak 2002).

There are strong Operations Management disadvantages to homework. Training is difficult-new techniques, impossible; machinery can only be what can fit in a home; quality control is limited; lengthy assembly lines cannot be formed-the number of operational issues is too long to list. However, there are strong reasons for firms to continue the practice. Labor can be exploited. It is piece-rate, as it is naturally done outside the view of any foreman, and it has been calculated that the piece-rate 
is about $1 / 4$ th the minimum wage (World Bank 2011, p. 175). For the particularly Machiavellian manager, virtually all safety regulations can be ignored. This practice also helps by providing a firm with surge capacity. Hiring/firing of workers is avoided. If more capacity is needed, reach out to more homeworkers. If less capacity is needed, don't send out work this week.

\subsection{Night Shift}

As a general extension of the prohibitions of purdah, factory owners in Bangladesh argue that "night shifts are not possible because no woman is willing to work at night" (Dannecker 2002, p. 127). Dannecker reports that women being out at night is considered shameful, and merely being outside the home at night risks detainment by police on suspicion of prostitution.

This religiously based prohibition has the force of law in many places. The ILO (2001, chp. 3) reports that laws of 54 countries still have a general prohibition on night work for women in 2001. Consequently, multinational firms expecting to amortize expensive equipment over three shifts may be disappointed.

\subsection{Layout}

Purdah also poses a challenge to facility layout in mixed gender environments and to situations where men are supervising women. An office or factory layout that works in one place simply cannot be used. Dannecker (2002, p. 136) reports that in a factory environment in devout Islamic areas where men are supervisors and women are workers, the layout must be changed so that the workers cannot be directly seen by the supervisors. Mirza $(1999$, p. 198) comments on an office environment: a female receptionist stand has to be out of the line of sight of the male executives passing through the office. Simply put, an architectural rendering cannot simply be transferred.

\subsection{Purdah Summary}

Regardless of one's view of the correctness of purdah, religious restrictions of women working exist in many countries and changes the operations of firms. The advice to management and Operations Management researchers here is to do their own version of "homework": determine whether these are issues that exist in a specific location. This means understanding a very local environment. For example, in India purdah is stronger in the states of West Bengal (Hussain and Siddiqui 2013) and Uttar Predesh (Basole 2012), and weaker or non-existent elsewhere. The attitudes that shape these decisions are regional.

\section{Confucianism}

The Analects of Confucius is one of the sacred texts of Confucianism. It was written in roughly 500 BCE.

Analects of Confucius, book 13, verse 18: "Talking with Confucius, the lord of She [Note: "She" is a place] said, 'In our district there's a fellow called Honest Body. When his father stole a sheep the son testified against him. Confucius said, 'In our district the honest people are different than that. A father covers up for his son; a son covers up for his father. There is honesty in that, too."

Analects book 9, verse 25: "The Master said, put prime value on loyalty and trustworthiness." (Watson 2007).

The Confucian world view is most usually associated with doing business in China, but the viewpoints resonate throughout the Far East and mark a significant contrast with the West. The two quotes relate to the Confucian primacy of relationships over rules. That is, a relationship is far more important than, say, a written contract.

Contract adherence is affected. To some-the mindset is called "universalists" by Trompenaars (1994) - a contract is a contract. It means precisely what its terms say. End of story. Paraphrasing 
Trompenaars, in the Confucian view a contract symbolizes the underlying relationship. It is an honest statement of original intent. Where circumstances transform the mutual spirit of that contract, then terms must be renegotiated to preserve the relationship. "The contract will be seen as definitive by the universalist, but only as a rough guideline or approximation by Particularists," or those with Confucian values (Trompenaars and Hampden-Turner 2011, p. 40).

Both sides appear to make immoral choices from the perspective of the other. What a Universarlist feels about someone with Confucian values is that "you can't trust him, he only helps his friends." What a Confucian feels about a Universalist is that "you can't trust him, he wouldn't help a friend" (Trompenaars and Hampden-Turner 2011, pp. 31-32).

This viewpoint factors in when the make/buy decision is made on outsourcing and contract specificity. In one of the few qualitative OM publications on the subject we find: "The practice of IS [Information Sytem] contract [sic] relies on trust rather than the very detailed written contract. Of course the contract should include the work scope, which will not include the detailed specs of functionalities" quoting a Korean manager on an IS outsourcing contract (Samaddar and Kadiyala 2006).

"The rationale for outsourcing in the Korean organization was that the tasks could not be completed in-house. Hence, if a task could be completed in-house then it would never be outsourced." "This finding also attests another attribute of the Korean culture, which, is the concept of an organization as an extended family. This concept of organization as an extended "family" provides job protection to the employees" (Samaddar and Kadiyala 2006).

\section{Christianity: Jehovah's Witness and Christian Science}

The intersection of religion and medical operations management is the subject of entire journals (e.g., Journal of Religion and Health, Journal of Spirituality in Health Care) and books (e.g., Dawson 2011a, 2011b). A basic tenet of the nexus of religion and medical operations is that, contrary to an implicit view of "the one best way" to perform medical procedures, that there should be, for lack of a better term, "faith considered medical services." The goal of research is different: finding best procedures given the constraints or advantages of a particular faith.

For example, Jehovah's Witnesses (Christian) refuse blood transfusions. The best way to perform surgery on a Jehovah's Witness has a combination of techniques not used on others to minimize blood loss: different body positions, body cooling, the operating theater is kept at $80 \mathrm{~F}$, and blood recirculation apparatus are used (Dawson 2011a, p. 174; JW.org has a large number of articles on alternatives to blood transfusions). Previously, gender segregation has been noted. It is common practice that only gender appropriate doctors see patients with those religious beliefs. An Islamic Fatwa: "a female doctor treats women and a male doctor treats men, and similarly in education. However, that a man treats a woman or vice versa, this is by no means allowed by Shari'ah [Islamic law]" (Baz 2018). If an improper gender mix must occur, there are rules to follow.

More mundane procedures differ as well. One of the first topics in Operations Research was solving the "diet problem"- getting appropriate nutrients with constraints on calories, fats, etc. Hospitals face unique religiously oriented diet problems, as meals must be Halal or Kosher for certain customers, Sikhs eat only Jhatka meat, and Jains are lactovegetarians. Many medicines are encapsulated by gelatin to dissolve in the stomach rather than the mouth—this method is prohibited by Islam, as the gelatin contains the prohibited ingredient stearic acid. One might be cavalier and say "it's their problem", but physicians are trying to heal, and if impious meals are delivered, they will simply not be eaten and the patient will suffer (Dawson 2011a).

A particular issue in the medical/religious world is at what stage in their illness patients see physicians. Christian Science was founded in the late 1800's. It has roughly 100,000 adherents in the US today. In addition to the Christian Bible, they also consider Mary Baker Eddy's book Science and Health to be revelatory. (Please do not confuse "Christian Science" with "Scientology"). Science and Health proclaims that disease does not exist. Illness is solely a manifestation of not being right with God. There is a similar view among Tibetan Buddhists (Pietkiewicz 2008, p. 150). By the time they deign to 
visit a physician these people have far more advanced cases and deny they are sick-so they must be treated differently. In a similar manner, Jains are noted for their detachment from pain (Pietkiewicz 2008, p. 73), so physicians must make note of their religious beliefs when assessing responses to questions about pain and what that means for their illness.

\section{Summary}

Overall, the quest for meaning can be seen as an innate human need. Religious belief is the main shaper of world view and provider of meaning for many. Of course, workers and customers will bring their religious views with them in business interactions.

Our contention is that researchers are losing out on important theoretical and practical findings because, collectively, we do not see the methods and conditions described in this work as "science." Our vision of "generalizability" is too narrow and does not accommodate some truths. Although the methods are different, the goal is similar. In the words of anthropologist Schwartzman (1993, p. 3) "the central problem for an applied anthropology of work is to find ways of improving the relationship between human potential and the productive process."

As described here, the religious beliefs of either employees or customers can have a disruptive influence on modeling results that mandate seats sold on an airline, where to locate a facility, whether to outsource, and a host of other operational choices.

Funding: This research received no external funding.

Conflicts of Interest: The author declares no conflict of interest.

\section{References}

Abdul-Aziz, Zalina, J. F. L. Chan, and Andrew V. Metcalfe. 2000. Quality practices in the manufacturing industry in the UK and Malaysia. Total Quality Management 11: 1053-64. [CrossRef]

Adam, Everett E., Lawrence M. Corbett, Benito E. Flores, Norma J. Harrison, T.S. Lee, Boo-Ho Rho, Jaime Ribera, Danny Samson, and Roy Westbrook. 1997. An international study of quality improvement approach and firm performance. International Journal of Operations \& Production Management 17: 842-73.

Al-Munajjid. 2018. Islam Question and Answer. Available online: https://islamqa.info/en/106815 (accessed on 5 October 2018).

Amin, Sajeda. 1999. The Poverty-Purdah trap in rural Bangladesh. Development and Change 28: 213-33. [CrossRef]

Anonymous. 2013. 'Ghostly' Happenings: Karachi Factory Workers' Mass Hysteria. Dawn. Available online: https://www.dawn.com/news/1052767/ghostly-happenings-karachi-factory-workers-mass-hysteria (accessed on 10 March 2018).

Anonymous. 2014. Evil Spirits in the Workplace Send Nepalese out in Protest. The Star Online. Available online: http://www.thestar.com.my/News/Nation/2014/01/13/Evil-spirits-in-the-workplace-send-Nepaleseout-in-protest/ (accessed on 7 December 2015).

Anonymous. 2016. Everybody into the pool. New York Times, June 1.

Basole, Amit. 2012. Knowledge, Gender, and Production Relations in India's Informal Economy. Ph.D. thesis, University of Massachusetts Amherst, Amherst, MA, USA.

Baz, I. 2018. Fatwas of Ibn Baz. Available online: http://www.alifta.net/fatawa/fatawaDetails.aspx?languagename= en\&View=Page\&PageID=5359\&PageNo=1\&BookID=14 (accessed on 10 October 2018).

BBC. 2018. Available online: Bbc.co.uk/religion/religions/Buddhism/subdivisions/Tibetan_1.shtml (accessed on 10 October 2018).

Cabanas, Walter, and Texas A\&M University, Houston, TX, USA. 2014. Personal communication. Cabanas is an oil firm executive.

Calder, Bobby J., Lynn W. Phillips, and Alice M. Tybout. 1981. Designing research for application. Journal of Consumer Research 8: 197-207. [CrossRef]

Calder, Bobby J., Lynn W. Phillips, and Alice M. Tybout. 1982. The concept of external validity. Journal of Consumer Research 9: 240-44. [CrossRef] 
Calder, Bobby J., Lynn W. Phillips, and Alice M. Tybout. 1983. Beyond external validity. Journal of Consumer Research 10: 112-14. [CrossRef]

Campbell, Heidi. 2010. When Religion Meets New Media. London: Routledge, Taylor and Francis Group.

Chin, Kwai-Sang, Hongyi Sun, Yan Xu, and Hongming Hua. 2002. A comparative study of quality management practices in Hong Kong and Shanghai manufacturing industries. International Journal of Management 19: 576.

Clark, N. 2016. Faith and its consequences. New York Times, February 21.

Colligan, Michael J., James W. Pennebaker, and Lawrence R. Murphy. 1982. A review of mass psychogenic illness in work settings. In Mass Psychogenic Illness: A Social Psychological Analysis. Edited by Michael J. Colligan, James W. Pennebaker and Lawrence R. Murphy. Hillsdale: L. Erlbaum Associates.

Continental Gold. 2018. Presentation to Faculty Development in International Business, U. Miami School of Business, in Medellin, Columbia. June 14.

Corbett, L. M., E. E. Adam Jr., N. J. Harrison, T. S. Lee, B. H. Rho, and D. Samson. 1998. A study of quality management practices and performance in Asia and the South Pacific. International Journal of Production Research 36: 2597-607. [CrossRef]

Crapanzano, Vincent. 1977. Introduction. In Case Studies in Spirit Possession. Edited by Vincent Crapanzano and Vivian Garrison. New York: Wiley and Sons.

Dannecker, Peter. 2002. Between Conformity and Resistance: Women Garment Workers in Bangladesh. Dhaka: University Press, Ltd.

Dawson, John. 2011a. Religion in Medicine, Volume I. Bloomington: Xlibris Corp.

Dawson, John. 2011b. Religion in Medicine, Volume II. Bloomington: Xlibris Corp.

Dedeoglu, Saniye. 2008. Women Workers in Turkey. London: Tauris Academic Studies.

Ewest, Timothy, ed. 2018. Faith and Work: Christian Perspectives, Research and Insights into the Movement. Charlotte: IAP.

Filistrucchi, Lapo, and Jens Prüfer. 2018. Faithful strategies: How religion shapes nonprofit management. Management Science 65: 188-208. [CrossRef]

Ganoza, R. 2018. Presentation to Faculty Development in International Business, Lima, Peru, June 4. Mr. Ganoza is VP-Business Development. Lima: Minera Buenaventura.

GMRG. 2018. Available online: Gmrg.org/publications (accessed on 26 July 2018).

Goreau, Angeline. 1996. Land of Elves and Trolls and Pretty Ponies. New York Times. Available online: https://www.nytimes.com/1996/05/12/magazine/land-of-elves-and-trolls-and-pretty-ponies.html (accessed on 9 October 2018).

Guggenheim, Noga, and Orit Taubman-Ben-Ari. 2014. Women who DARE: driving attitudes and road experiences among ultraorthodox women in Israel. Gender, Place E Culture 21: 533-49.

Harpin, Lee. 2017. Police board easyJet Tel Aviv to London Flight. The Jewish Chronicle. February 15. Available online: Thejc.com/news/uk-news/easyjet-1.432766 (accessed on 23 February 2017).

Hauksdottir, G. 2016. Construction disrupted by elves or hidden people in Iceland. IceNews. Available online: http://www.icenews.is/2016/07/15/construction-disrupted-by-elves-or-hidden-people-in-iceland/ \#axzz4fBeMr1Rb (accessed on 24 April 2017).

Hines, Nickolaus. 2018. 4 Times Iceland Made Major Decisions Based on Elves. Available online: https: //allthatsinteresting.com/iceland-elves (accessed on 8 October 2018).

Hussain, Nazmul, and Farasat Ali Siddiqui. 2013. Muslim female work participation in West Bengal, India. Women's Studies 42: 291-313. [CrossRef]

International Labour Organization. 2001. General Survey of the Reports Concerning the Night Work (Women) Convention, 1919 (No.4), the Night Work (Women) Conventions (Revised), 1948 (No.89) and the Protocol of 1990 to the Night Work (Women) Convention (Revised) 1948. Geneva: International Labour Organization.

International Labour Organization. 2012. Promoting the ILO Home Work Convention (C177) and the Rights of Homeworkers. Geneva: ILO.

Kessler, C. 1977. Confict and sovereighty in Kelatan Malay spirit possession and shamanism. In Case Studies in Spirit Possession. Edited by Vincent Crapanzano and Vivian Garrison. New York: Wiley, pp. 295-331.

Khattak, Saba Gul. 2002. Subcontracted work and gender relations: The case of Pakistan. In The Hidden Assembly Line: Gender Dynamics of Subcontracted Work in a Global Economy. Edited by Balakrishnan R. Bloomfield: Kumarian Press.

Lewis, Michael. 2011. Boomerang: Travels in the New Third World. New York: W. W. Norton \& Company. 
Lyall, Sarah. 2005. Building in Iceland? Better clear it with the elves first. New York Times. July 13. Available online: https:/www.nytimes.com/2005/07/13/world/europe/building-in-iceland-better-clear-it-with-theelves-first.html (accessed on 8 October 2018).

Lynch, John. 1982. On the external validity of experiments in consumer research. Journal of Consumer Research 9 : 225-39. [CrossRef]

Lynch, John. 1983. The role of external validity in theoretical research. Journal of Consumer Research 10: 109-11. [CrossRef]

Marshall, Andrew. 2011. What's causing 'mass faintings' at Cambodian factories? Time. September 20. Available online: Content.time.com/time/printout/0,8816,2093516,00.html (accessed on 19 December 2014).

McAlexander, James H, Beth Leavenworth Dufault, Diane M. Martin, and John W. Schouten. 2014. The marketization of religion: Field, capital, and consumer identity. Journal of Consumer Research 41: 858-75. [CrossRef]

McCann, Dennis. 1995. A word to the reader. In On Moral Business, Classical and Contemporary Resources for Ethics in Economic Life. Edited by Max L. Stackhouse, Dennis P. McCann, Shirley J. Roels and Preston N. Williams. Michigan: Eerdsmans Publishing, Grand Rapids.

McGuire, Sean T., Thomas C. Omer, and Nathan Y. Sharp. 2011. The impact of religion on financial reporting irregularities. The Accounting Review 87: 645-73. [CrossRef]

Mehta, Hemant. 2018. Ultra-Orthodox Jews delayed a flight (again) by refusing to sit next to women. Friendly Atheist. July 2. Available online: http://friendlyatheist.patheos.com/2018/07/02/ultra-orthodox-jews-delayeda-flight-again-by-refusing-to-sit-next-to-women/ (accessed on 10 October 2018).

Metters, R., D. Marshall, and M. Pagel. Forthcoming. Culture research in operations management. Foundations and Trends in Operations Management.

Miller, David W., and Timothy Ewest. 2013. The present state of workplace spirituality: A literature review considering context, theory, and measurement/assessment. Journal of Religious $\mathcal{E}$ Theological Information 12: $29-54$.

Mirza, Jasmin. 1999. Accommodating purdah to the workplace: gender relationships in the office sector in Pakistan. The Pakistan Development Review 38: 187-206. [CrossRef]

Mitroff, Ian I. 2003. Do not promote religion under the guise of spirituality. Organization 10: 375-82. [CrossRef]

Nash, June. 1993. We Eat the Mines and the Mines Eat Us: Dependency and Exploitation in Bolivian Tin Mines. New York: Columbia University Press.

National Geographic. 2016. The Pyramid Builders' Village in Egypt. Available online: https://www. nationalgeographic.com.au/history/the-pyramid-builders-village-in-egypt.aspx (accessed on 19 September 2018).

Ong, Aihwa. 1987. Spirits of Resistance and Capitalist Discipline: Factory Women in Malaysia. Albany: State University of New York Press.

Ong, Aihwa. 1988. The production of possession: Spirits and the multinational corporation in Malaysia. American Ethnologist 15: 28-42. [CrossRef]

Phoon, W.H. 1982. Outbreaks of mass hysteria at workplaces in Singapore: some patterns and modes of presentation. In Mass Psychogenic Illness: A Social Psychological Analysis. Edited by Michael J. Colligan, James W. Pennebaker and Lawrence R. Murphy. Hillsdale: Lawrence Erlbaum Associates.

Pietkiewicz, Igor. 2008. Culture, Religion, and Ethonomedicine. New York: University Press of America.

Radford, Benjamin. 2013. Is a Ghost Lurking in a Factory Toilet? LiveScience. Available online: http://www. livescience.com/37644-ghost-exorcism-bangladesh.html (accessed on 16 July 2015).

Raghunathan, T. S., S. Subba Rao, and Luis E. Solis. 1997. A comparative study of quality practices: USA, China and India. Industrial Management \& Data Systems 97: 192-200.

Rao, S. Subba, T.S. Raghunathan, and Luis E. Solis. 1997. A comparative study of quality practices and results in India, China and Mexico. Journal of Quality Management 2: 235-50. [CrossRef]

Rowbotham, Sheila. 1993. Homeworkers Worldwide. London: The Merlin Press.

Rungtusanatham, M., C. Forza, B. Koka, F. Salvador, and W. Nie. 2005. TQM across multiple countries: Convergence hypothesis versus national specificity arguments. Journal of Operations Management 23: 43-63. [CrossRef]

Samaddar, Subhashish, and Savitha Kadiyala. 2006. Information systems outsourcing: Replicating an existing framework in a different cultural context. Journal of Operations Management 24: 910-31. [CrossRef] 
Schwartzman, Helen. 1993. Ethnography in Organizations. Thousand Oaks: Sage.

Shahriari, Sara. 2017. Bolivia's witch markets offer llama fetuses and more. Huffington Post. Available online: https://www.huffingtonpost.com/2009/10/30/bolivias-witch-markets-of_n_339981.html (accessed on 3 October 2018).

Shapira-Rosenberg. 2010. Excluded, for God's Sake: Gender Segregation in Public Space in Israel. Tel Aviv: Israel Religious Action Center.

Shu, Tao, Johan Sulaeman, and P. Eric Yeung. 2012. Local religious beliefs and mutual fund risk-taking behaviors. Management Science 58: 1779-96. [CrossRef]

Stackhouse, Max L., Dennis P. McCann, and Shirley J. Roels. 1995. On Moral Business, Classical and Contemporary Resources for Ethics in Economic Life. Grand Rapids: Eerdsmans Publishing.

Staff, Toi. 2018. NY-Israel flight delayed by ultra-Orthodox men's refusal to sit next to women. The Times of Israel. June 24. Available online: https://www.timesofisrael.com/flight-delayed-over-ultra-orthodox-mens-refusalto-sit-next-to-women/ (accessed on 10 October 2018).

Tata, Jasmine, Sameer Prasad, and Jaideep Motwani. 2000. Benchmarking quality management practices: US versus Costa Rica. Multinational Business Review 8: 37.

Taussig, Michael T. 1980. The Devil and Commodity Fetishism in South America. Chapel Hill: University of North Carolina Press.

Trompenaars, Fons. 1994. Riding the Waves of Culture. London: International Management Publishers.

Trompenaars, Fons, and Charles Hampden-Turner. 2011. Riding the Waves of Culture: Understanding Diversity in Global Business. Boston: Nicholas Brealey International.

Tu, D. 1997. Tibet's Population: Past and Present. China Population Today 14: 4-6. [PubMed]

United, Airlines. 2017. Personal communication from United employees.

Wainwright, Oliver. 2015. In Iceland, 'respect the elves-Or else'. The Guardian. Available online: https: //www.theguardian.com/artanddesign/2015/mar/25/iceland-construction-respect-elves-or-else (accessed on 9 October 2018).

Wallace, Julia. 2014. Workers of the world, faint! The New York Times, January 19, 4.

Watson, Burton. 2007. The Analects of Confucius. New York: Columbia U. Press.

Woodhead, Linda, and Christopher Partridge. 2016. Religions in the Modern World: Traditions and Transformations. Edited by Woodhead Linda, Christopher Partridge and Hiroko Kawanami. London: Routledge, chp. 1.

Woodhead, Linda, Christopher Partridge, and Hiroko Kawanami. 2016. Religions in the Modern World: Traditions and Transformations. London: Routledge.

World Bank. 2011. World Development Report 2012: Gender Equality and Development. Washington: The World Bank.

Yavas, Burhan F. 1995. A comparison on the quality perceptions of US and Asian firms in the electronics industry. MIR: Management International Review 35: 171-88.

Zambia Chamber of Mines. 2015. Presentation by Mining Executives to Faculty Development in International Business Group, U. Lusaka: Maryland CIBER.

Zhao, Xiande, Sharad K. Maheshwari, and Jincheng Zhang. 1995. Benchmarking quality practices in India, China and Mexico. Benchmarking for Quality Management \& Technology 2: 20-40.

(C) 2019 by the author. Licensee MDPI, Basel, Switzerland. This article is an open access article distributed under the terms and conditions of the Creative Commons Attribution (CC BY) license (http://creativecommons.org/licenses/by/4.0/). 